\title{
Developing International Social Capital: the role of communities of practice and clustering
}

\author{
Berrbizne URZELAI* \\ University of the West of England (UK) \\ berrbizne2.urzelai@uwe.ac.uk \\ Francisco PUIG \\ Universitat de València (Spain) \\ francisco.puig@uv.es
}

\begin{abstract}
One criteria regarding where to invest in foreign markets is linked to the international social capital (ISC) that exists on the place, which enables the access to local knowledge and other location-specific advantages. There are alternative ways to create and make use of that ISC that are still unexplored by International Business literature. In this paper, we study the geographic communities of practice ( $\mathrm{CoP}$ ) that are formed by FDI firms from the same country-of-origin (the so-called country-of-origin clusters). For that purpose, the paper adopts a qualitative methodological approach through an inductive case study of expatriates from 13 Spanish subsidiaries co-located in China. Our findings suggest that there are particular mechanisms based on the informal connections and repeated interactions facilitated by a common language and non-competitive relationships that create an ISC in the CoP. Moreover, our analysis shows there is a heterogeneity in the way these mechanisms are developed and used by the member firms, and this is due to organizational and individual factors, as well as leadership dynamics. Our work contributes to Internationalization and Network theories by identifying unexplored mechanisms through which the ISC is developed at the host country level. Besides, it helps identifying competences (i.e. clustering competences) that help expatriate managers to be successful in their international assignments.
\end{abstract}

\section{Key words:}

International social capital, communities of practice, co-location, cluster, China. 


\section{INTRODUCTION}

Foreign direct investment (FDI) is a decision that implies dealing with the location choice. Important aspects of this decision are related to the identification, study and selection of a location and the prediction of how this location may change. In line with this, the literature shows that there is a research interest that has evolved from an approach that is based on macro-level factors (space) that influence that decision (mainly economic factors), to an approach that considers the micro-level or place factors (regions, clusters, provinces and cities), which take into account the socio, economic and institutional context of the location (Kim and Aguilera, 2016; Wu et al., 2017).

Recently, Jain et al. (2016) and Nielsen et al. (2017) have published extensive literature about the factors that attract FDI, and from their work we can conclude that, in IB research on foreign location choice, the place now matters more than the space. As Beugelsdijk et al. (2010) and Nicholson et al. (2017) have suggested, this implies a closer attention to theories on Economic Geography and clustering.

One of the phenomena that has been most researched in the current literature on location choice is FDI agglomerations. Jones (2017), found that the majority of the studies focus on analysing the effect and externalities of agglomeration economies on FDI and/or the reasons why the firms decide to co-locate with other firms, especially with those with the same activity (industrial clusters). Wu et al. (2017) have examined how host country institutional factors influence agglomeration and they found that foreign firms respond to institutional pressures by agglomerating in countries characterized by collectivism and economic and political uncertainty. However, the research done is scarce and there are not many studies that analyse the location choice when the firms have the same nationality (country-of-origin clusters) (COC) (Alcacer and Chung, 2014; Alfaro and Chen, 2014). 
This is surprising as the latest research evidences that when this co-location is in the form of COC, firms benefit from synergistic advantages that improve their lack of information and knowledge about the host country context, as well as their lack of social and business networks (Tan and Meyer, 2011).

As Kim and Aguilera (2016) and Nielsen et al. (2017) claim, we know why foreign firms co-locate and what the effect of co-location are. Literature evidences that the determinants of location choice vary between firms and regions (Shen and Puig, 2018). Even if we know that there are specific benefits associated to one or another type of clusters (Tan and Meyer, 2011), there is a need to study how the internationalized firms within those clusters benefit from those externalities and learn from each other. This implies the necessity to focus the research on the networking element of clustering.

In this paper, we look at the phenomena of the geographical clustering from an original point of view, the communities of practices created by expatriates in COCs. In this paper we define the expats communities of practices (CoPs) as groups of managers geographically very close and informally bounded through an exposure to a common set of problems and challenges derived from their lack of local knowledge. An important effect of this type of clustering is the generation of International Social Capital (ISC), a strategic resource that can be used to reduce firms' liabilities in emerging countries (Masciarelli, 2011).

Although the concept of CoP is not new (Lave and Wenger, 1991; Brown and Duguid, 1991, Wenger et al, 2002) not many authors have worked on it from an international business point of view, and when they have done it (see Welch and Welch, 2015; Raab et al., 2014, Buckley and Carter, 2004; Noorderhaven and Harzing, 2009; Haghirian, 2006) the approach taken has been intra-organizational, i.e. among units of the same MNC. 
Authors such as Cox (2005) or Roberts (2006) suggest that there is a need of research where the CoPs are analyzed across organizational boundaries. In line with authors such as Tallman and Chacar (2011) our research looks at the CoPs created within geographical clusters and places at an inter-organizational and international perspective. Under this point of view, the CoP approach has advantages that enable us to study, in more detail, the mechanisms through which the ISC adds value, and how the diversity of geographically clustered expatriates influences the way this capital is created and exploited in the host market.

Therefore, the objective of this research is to analyse the mechanisms through which geographic CoPs of expatriate managers in COCs develop and use its ISC. To accomplish this, we have conducted face-to-face semi-structured in-depth interviews to 13 Basque (Spain) expatriates working in a COC, the industrial park of Mondragon in Kunshan (China). The paper is structured as follows. First, the literature review is presented. Then the methodological approach will be explained, which is followed by the findings and discussions. We will conclude the paper with research contributions, limitations and implications for future research.

\section{LITERATURE REVIEW}

\section{The place in the host country as a learning and knowledge platform}

Where to localize in foreign markets is one of the most critical decisions in firms' internationalization strategy (Dunning, 2009; Paul et al., 2017). However, IB literature has tended to study this aspect from a country-level point of view (space) and not much in terms of the place. Space refers to physical distance and area (where a particular process is happening) (Anderson, 2012). Place aims to capture the specificity or 
uniqueness of particular places (embedded in environmental, social, cultural, institutional and political context) (McDonald et al., 2018).

The literature suggests that foreign investors confront a number of location-specific disadvantages as compared to national firms when they enter a new foreign market (Hymer, 1960). Broadly speaking, foreign firms are unable to access and absorb the information and resources available in the host country as easily as the local firms, who are much more embedded into the local context. In comparison to developed markets, emerging markets are featured as highly uncertain, poorly regulated and weak local institutions (Peng et al., 2008) so foreign investors may face a competitive disadvantage arising from their lack of information knowledge in those markets. The lack of institutional strength in countries such as China make economic actors rely on informal trust-based relationships where cooperation and co-location is a way to protect their interest (Mesquita and Lazzarini, 2008; Opper and Nee, 2015) and social proximity compensate their liabilities (Wu et al., 2017). In other words, the place matters.

This means that the problems and opportunities that companies face in international operations are becoming less and less a matter of country-specific questions, and increasingly related to issues of relationships and networks (liability of outsidershipLOO). In this sense, the Uppsala revisited model (Johanson and Vahlne, 2009) emphasize the need to establish a relationship with other members of the network to obtain local knowledge and information. In the context of China, the LOO is also related to creating and developing guanxi, a web of connections that can be critical to do business and gain an edge over competitors and succeed in the internationalization activities of the firm (Park and Luo, 2001; Yeung and Tung, 1996) and can be construed as one type of social capital that connects key boundary people across various social groups and encourages them to pool resources (Su et al., 2009). 
The relationship between investment, networking and clusters can be seen no longer with clusters as the outcome of FDI, but as the precondition for attracting FDI (De Propris and Driffield, 2006). In countries such as China, special open statuses of economic zones could make localities attract more foreign capital than others. In fact, for local government officials the amount of investment that they attract to the region is an important promotion criterion. It is believed that this decentralization can create non-tariff barriers for companies (He et al., 2007). Therefore, the intangible value that clusters provide as learning and knowledge platforms, is an important criteria for firms to select a specific location or place.

In IB literature two of the most visible forms of geographical agglomerations are the industry clusters and the COCs (Stallkamp et al., 2017). While the former is more related to competitive relationships and industry-specific knowledge and resources, COCs enable the member firms to have easier and more frequent access to a variety of local and market related knowledge and typically exhibit cooperative inter-firm relations and a high level of trust (Tan and Meyer 2011). Co-locating and interacting actively with managers from the same origin in a specific place can facilitate the creation of the so-called ISC, which has to do with the tacit knowledge and resources that help firms of that network act in an isomorphic manner, gain legitimacy in the local environment, overcome LOO, and reduce knowledge-expropriation hazards or leakages (Tan and Meyer, 2011, Liao and Yu, 2012).

As Wenger et al. (2002:7) state, "success in global markets depends on communities sharing knowledge across the globe". Learning and development is not only about experience but also about social learning and relationships (Garavan et al., 2012). For example, in CoPs the learning is associated to a collaborative problem solving group that uses storytelling for that purpose (Brown and Duguid (1991). In our case, the expats have different ways in doing this. They often mention the daily lunch breaks when they all meet in the same 
table and share experiences, problems and knowledge. Besides, they mentioned that they call each other for particular topics too. The formal gatherings are linked to the annual meetings with the manager of the General Service company and discuss issues related to the whole business park.

To sum up, when firms analyze the localization of FDI they should look a the sub-regional level of the location, i.e. the place. By co-localizing with other firms they can benefit from the acquisition of ISC, an exclusive resource that help them surpass the liabilities of being a foreign firm. However, as various authors (Mariotti et al., 2010; Tallman et al., 2004) point out, geographical proximity is necessary to promote social learning and local knowledge acquisition due to the regular and direct face-to-face dimension but it is not sufficient to generate interaction between agents. 


\section{The role of the geographical communities of practice (CoPs) as a trigger of social}

\section{capital}

In line with Wenger et al. (2002: 7), CoPs are defined as 'groups of people who share a concern, a set of problems, or a passion about a topic, and who deepen their knowledge and expertise in this area by interacting on an ongoing basis'. Members are driven by a desire and need to share problems, experiences, insights, templates, tools and best practices (Hubert et al., 2001) and their interaction can be face-to-face or virtual (Peng and Meyer, 2011). Cummings and Van Zee (2005) argue that networks and CoPs are part of a continuum, ranging from informality- spontaneous groups of professionals forming a CoP- to formality, more institutionalized in the form of a network, including a "management unit" whose role it is to facilitate the networking process. In our daily lives we find examples of groups of people that create communities of practice to solve technical issues, learn a language or share pedagogical practices.

Wenger et al. (2002) describe some of the elements of the CoP: a) the members do not necessarily work together every day but they meet because they find (work and personal) value in their interaction; b) they share information and help each other, they discuss situations, aspirations and needs; c) they may create tools, manuals or other documents or they may simple develop a tacit understanding; d) over time they develop a body of common knowledge, practices, and approaches as well as personal relationships or even a sense of identity.

Kogut and Zander (1993) conceptualized MNCs as 'social communities' and emphasize the importance of the 'cognitive properties of individuals', 'shared identities', and 'established routines of cooperation' within MNCs. In line with this, the idea of "the firm 
as a community of practice" (CoP) (Buckley and Carter, 2002) is especially relevant. Welch and Welch (2015) look at the concept of CoP from an international human resource management point of view and acknowledge that it contributes to building global career capital. Other authors such as Raab et al. (2014), Buckley and Carter (2004) or Noorderhaven and Harzing (2009) study how knowledge sharing or combination that takes place within MNCs. Besides, Haghirian (2006) state that communities of practice face new challenges with knowledge transfer happens in an international setting.

One of the key roles of CoPs is to build social capital among members, which in turn enables community members to effectively manage their organizational knowledge (Lesser and Prusak, 1999) and improve performance (Lesser and Storck, 2001). The benefits of the CoPs could be for business (drive strategy, diffuse best practices, crossfertilize ideas, etc.), for the community (build common language, methods and models, establish knowledge and expertise in a larger population, help knowledge retention, etc.) or for the individuals (efficiency, sense of safety, learning-focused sense of identity, offer contribution and face challenges, etc.) (Allee, 2000; Chu et al., 2012; Guercini et al., 2017).

However, at this point we could wonder, what is the real interaction between firms and the place in which they are located?. MNEs' presence in different local contexts with varying institutions and resources is an important stimulus to innovation but the management of both corporate and external networks is complex (Nielsen et al., 2017). This multiple embeddedness creates complex managerial challenges for MNEs to convert opportunities of knowledge creation into success stories (Peng and Meyer, 2011). Few firms have been able to connect local CoPs with the MNE's internal CoP (Tallman and Chacar, 2011). This lack of connection can be reduced by encouraging employees to mobilize their personal networks and by firms taking part in, as well as organizing, 
networking activities that build trust and reciprocity, leading to enhanced social capital (Pattinson and Preece, 2014). In other words, while it is a condition to be co-located, this is not enough to acquire and develop ISC. Besides, the characteristics of the CoP in terms of its size, diversity and nature of its elements require a deeper understanding of this phenomena.

Therefore, our study tries to extend the existing clustering literature by shifting cluster scholars' focus towards the idea of CoP. It broadens the literature about FDI geographical agglomerations by considering that inter-subsidiary collective learning and knowledge sharing could create the social capital that influences the firms' location choices.

\section{International social capital (ISC): the relational strategic resource of the place}

Since Jacobs's work in 1961 many studies and diverse disciplines have analysed social capital (Coleman, 1988; Putman, 1995; Burt, 2002; Garcia-Villaverde et al., 2017). Nahapiet and Ghoshal (1998: 243) define social capital as "the sum of the actual and potential resources embedded within, available through, and derived from the network of relationships possessed by an individual or social unit". Some studies have found positive relationships between (international) social ties and capital and firms' performance (Adler and Kwon 2002; Freeman et al., 2010) and internationalization (Ellis and Pecotich, 2001; Harris and Wheeler, 2005). Social capital can contribute towards acquiring foreign market knowledge (Sharma and Blomstermo, 2003; Oviatt and McDougall, 2005) and access resources and international opportunities that overcome the LOO (Coviello, 2006). Besides, it facilitates flows of information, exert influence on decision makers, act as individual's social credentials and reinforce identity and recognition (Lin, 1999). One of the factors why social capital increases the efficiency of knowledge transfer is because it encourages cooperative behaviour (Gooderham, 2007). 
In fact, knowledge management is best facilitated by informal social capital, which refers to the informal benefits individuals and organizations derive from their social structures and networks (Kostova and Roth, 2002).

Previous research (Chen and Chen, 1998; Chetty and Blankenburg Holm, 2000; Zhao and Hsu, 2007) has shown that social capital can help reduce psychic distance and influence foreign market entry decisions. Freeman et al. (2012) found that firms initially seek knowledge situated in the home operational context to leverage their entrance into their target Asian markets. Firms that enter a market that is not highly internationalized tend to follow the route of agents by investing in those relationships or acquire a firm with an established position in the international network to benefit from its knowledge and network links (Susman, 2007). The social network then plays a facilitator role for companies in foreign destinations.

Despite of this, most applications of the emerging social capital theory have been in the domestic context (e.g., Tsai \& Ghoshal 1998; Yli-Renko et al. 2001), but this study discussed its benefits and use in the international context. Masciarelli (2011: 81) defines the concept of international social capital (ISC) as the relationship that the firm establishes with foreign actors that have access to various knowledge domains. The author suggests that firms must invest in ISC in order to facilitate the acquisition, coordination and integration of complex flows of knowledge, benefit from cost savings and increase efficiency. She found that it guarantees a higher level of control and reinforces the positive effect on firms' performance. As Partanen et al. (2008) found, that the role that the different dimensions of social capital play varies in developing, maintaining and utilizing the partnership and network relationships. In other words, there are differences and alternative mechanisms through which the ISC plays its role. 
In this sense, Thomas' (1994) model of expatriates' boundary-spanning behaviour identifies the environmental uncertainty as a key antecedent of expatriate boundaryspanning activity, and predicted that, under conditions of uncertainty, the expatriate would increase his or her level of boundary-spanning behaviour (Thomas, 1994: 151). Both Thomas (1994) and Au \& Fukuda (2002) analysed the antecedents and outcomes of boundary roles, but neither of them focused on the construct of that role.

Johnson and Duxbury (2010) go beyond this approach and extended the conceptualizations of the boundary role to the work of the expatriate. Their findings suggest that interpersonal relationships may be the cornerstones of the role and the enablers of other cross-boundary resource exchanges. Greater numbers of expatriates performing these kinds of boundary-spanning roles will support the dual role that subsidiaries play within their organizations and the local host contexts. Smale et al. (2015) found that dual values-based identification (with both the whole corporation and the local subsidiary) is associated with acculturation and first-hand contact at the individual level, and a supportive social context for affective learning at the organizational level. Even more, if those boundary spanners have both cultural and language skills, they will perform more functions and be more valuable than those with only cultural skills (BarnerRasmussen et al., 2014).

For example, expatriates mutually engage in social interactions with each other through activities such as sporting events and family activities (Tung, 1998; Tan and Meyer, 2011). These social interactions not only provide valuable personal social support for the expatriates and their families but also play a central role in the sharing of knowledge about the local market (Feldman and Bolino, 1999; Tan and Meyer, 2011). The social network developed by expatriates at the micro, interpersonal level feed into a macro, interorganizational strategy of depending on networks to expand the firm, thus giving rise to 
a micro-macro link (Peng and Luo, 2000; Peng et al., 2008). It is thus imperative for international business scholars to examine the multi-level social interactions among expatriates and their parent firms because both the micro and macro levels are inextricably connected.

While Wenger et al. (2002) explain the elements of CoPs from 3 aspects: 1) the domain of knowledge, which defines a set of issues; 2) the community of people who care about this domain; and 3) the shared practice that the community develops to be effective in their domain, Nahapiet and Ghoshal (1998) categorized social capital into structural, relational, and cognitive dimensions. In the field of $\mathrm{IB}$, all of these dimensions affect the knowledge acquisition and knowledge transfer in multinational corporations (Inkpen and Tsang, 2005; Maurer and Ebers, 2006). For this reason, those dimensions need to be analyzed in order to facilitate the understanding of the multi-level mechanisms through which the ISC is created, developed and used. Given the generalized use in the literature in International Business, we will adopt the Nahapiet and Ghoshal (1998) definition.

The structural dimension_highlights the network configuration and structure (Lindstrand et al., 2011) and describes the connections between individual members of the network (Coleman, 1988). Inkpen and Tsang (2005) describe network ties (the ways the actors are related), network configuration (hierarchy, density, connectivity) and network stability (change of membership in a network) as part of this dimension. For instance, the structural dimension of a multinational firm can be analysed by looking at the intra and inter subsidiary relationships. The cognitive dimension conveys the perspectives, narratives, values, language, and goals that the individuals share (Nahapiet and Ghoshal, 1998). It makes reference to a mutual understanding through a common language or sharing experiences. It has impact on resource acquisition and exchange within the network (Tsai and Ghoshal, 1998; Lindstrand et al., 2011). For instance, the perception that the 
expatriates have about their belongingness to the cluster or the CoP. The relational dimension includes the personal relationships that individuals develop through repeated interactions (Håkansson and Johanson, 1993; Gooderham, 2007). The main components are trust, trustworthiness, and social interaction (Lindstrand et al., 2011). Trust is one of the key elements that facilitate knowledge transfer and collaboration (Inkpen and Tsang, 2005; Lui, 2009; Welter, 2012). For instance, the guanxi network that they develop in China.

Summarizing, our literature review allows us to rely on the idea that COC enables learning from a living place through an inter-organizational expat's $\mathrm{CoP}$, which generates value in the form of ISC, and that the ISC is a strategic resource that can be used to reduce their liabilities in emerging countries and be more competitive. In the next sections we will analyse how it is created and exploited in this market.

\section{RESEARCH METHODOLOGY}

\section{The case study}

We find determinant in our research the study of the people's experiences to understand the phenomena of ISC development process within a cluster setting, which makes our research strategy to be closer to a case study and qualitative approach (Ghauri, and Grønhaug, 2005). Several authors (Birkinsaw et al., 2011, Doz, 2011; Welch et al., 2011) have reclaimed a place for qualitative research as an integral part of IB research. According to Yin's (2009) classification our research is based on a single embedded case study as we focus on a network of several Spanish expatriates working in different companies in a business park in China. We find China and the Park of Kunshan as a adequate context of analysis due to its relevance more than its representativeness 
(Eisenhardt, 1989; Yin, 2009) but the findings could be transferable to other country-oforigin agglomerations as well as MNCs agglomerations.

Besides, it is important to mention that the Spanish firms we are analysing come from a specific northern area, the Basque Country, a region characterized by its strong global entrepreneurship attitude (EJ-GV, 1999, Ács et al., 2015) and strong managerial practice and institutional factors that support the internationalization of firms (García- Cabrera and García-Soto, 2017). It should be also remarked that most of the firms in the sample belong to Mondragon Corporation, the first business group in the Basque Country and seventh in Spain (Mondragon, 2017). Mondragon is considered a case that demonstrates a process of entrepreneurship that is adaptable to other depleted communities (Johnstone and Lionais, 2004). Thus, the sample firms share a common culture and background.

The COC in Kunshan (in China it is called Spain Industrial park/ 西班牙工业园) is the first international business park that SPRI (Basque Government office business promotion) supported through a collaboration agreement signed in Qiandeng, a town under the jurisdiction of Suzhou in the Yangtze River Delta, between the two large metropolises of Shanghai and Suzhou. In Dec. 2014, the park was awarded the honour of Demonstration Area of China Spain Industrial International Cooperation by Technology Ministry. The park is located in Qiandeng, a town under the jurisdiction of Suzhou in the Yangtze River Delta, Jiangsu province. In line with Wenger et al (2002) our case study could be defined as a CoP characterized as small, short-lived, co-located (same place), heterogeneous (bring people from different disciplines), across-boundaries (with managers that belong to different organizations), spontaneous but partially intentional, and mainly unrecognized but a bit institutionalized.

\section{$\underline{\text { Sample and data collection }}$}


According to the Directory of firms of the Spanish Chamber of Commerce in China (2013) the sample represents $46 \%$ of the Spanish firms in Jiangsu and $33 \%$ of the Basque firms in China. The details given about the interviewees, companies, context and methodology help to enhance the replicability of the research. As business directories were incomplete so the researchers used personal contacts to get in touch the firms there. Access to data has been achieved through constant emails and visits to the companies and meetings with members of the Spanish chamber of commerce in China, Basque promotion agency office in Shanghai and Mondragon Corporation representatives in the country. To become familiar and get access to the members, the fieldworker visited the field 2-3 days a week for two months in 2013, spending time with expatriates during lunch, factory visits, and spare time and travelling times. Entering the field allowed the researcher to take advantage of emergent themes and unique case features (Eisenhardt, 1989). The fieldworker attempted to build understanding of their relationships and interactions and become familiar with their everyday talk.

The research process included different sources and methods, such as document analysis, informal conversations and formal semi-structured interviews. Pre-interviews and pilot tests with middle level managers were conducted in order to pre-test the validity of the interview protocol and the understanding of the questions. Around 18 hours of recorded semi-structured interviews were collected from dialogues with 13 expatriate managers of the companies located in the Mondragon Kunshan Business Park. Eisenhardt (1989) suggests that four to ten cases can usually serve as an adequate sample as with more than ten cases it becomes difficult to cope with the volume of data and saturation. All the interviewees were at the maximum management level of the subsidiaries (General Manager/ CEO) to make use of theoretical sampling, "which means that the investigator examines individuals who can contribute to the evolving theory" (Creswell, 1997: 155). 
Document analysis made the authors understand the background of each company through the revision of annual reports, the organization's internet and intranet website or internal emails. Secondary data from Bureay van Dijk's Orbis database was also used to cross-check, complement validate primary data (Yin, 2009). The fieldworker took part in several spontaneous conversations during lunch and coffee breaks at the park itself as well as in out-of-work events organized by the Basque House in Shanghai. These conversations provided a more detailed understanding of staff members' opinions and feelings.

The one-to-one face-to-face semi-structured interviews (see appendix 4) include questions that aim to explain how that $\mathrm{CoP}$ of COCs creates and develops the ISC. The structure of the interview guide was developed following the dimensions and factors identified in the literature by Nahapiet and Ghoshal (1998) (structural, cognitive and relational). For instance, in the structural dimension we look at how the network is configured and how the individuals are connected and related (ties), while in the cognitive dimension we measure elements such as the congruence level or feeling of belonging of the members. Strong ties are crucial for knowledge sharing and development (especially when we talk about tacit knowledge) as they can facilitate the development of common goals, compatible systems and cultures and routines needed to engage in mutual activities (Gnyawali et al., 2009). It is believed that network managers can build a shared meaning through specific practices such as the creation of network-specific goals (Wegner et al., 2012). The cognitive dimension can be found in the notion of feeling of belonging in industrial districts (Garcia-Villaverde et al., 2017). Shared identity is a strong predictor of relationship formation not only among individuals but also among organizations (Chung et al., 2000) and be produced by different types of conversations that connect the participants (Hardy et al., 2005). On the other hand, the main components of the relational 
dimension are trust, trustworthiness, and social interaction between the individuals (Lindstrand et al., 2011). We also included China-specific factors such as the development of guanxi, which could be related to the extent to which people willingly recognize obligations, harmony, and reciprocation in their daily socialization ( $\mathrm{Su}$ et al., 2009).

\section{Post-tests, triangulation and data analysis}

Reliability or internal validity and dependability/ repeatability of the research was improved by employing a case study protocol (Maxwell, 2005; Yin, 2009). Information about the protocol can be found in appendix (4). The prolonged stay in the research setting, document analysis or the relationship maintained with the interviewees could also be considered as techniques that aim to strengthen the reliability and credibility of the research. In following steps the interviewees will also double check the quotations taken for the research paper. Construct validity was satisfied by including multiple sources of evidence (physical artefacts, interviews, observation of the setting, internal documents).

All interviews were audio-recorded, transcribed verbatim in their original language of the responses (English, Spanish, Basque), and evaluated through multiple rounds of independent assessments by the authors in order to ensure the reliability of findings (Yin, 2009). Content analysis (Huberman and Miles, 1994) was then used to analyze the qualitative data collected. The data was structured in tables and diagrams and revisited in order not to lose any insights with regards to the research questions. Categories (Gioia et al., 2013), codes (Van Maanen, 1988) and clusters of themes emerged through the analysis As Sinkovic et al. (2008) argued, the use of formalised software-based procedures should be used for the analysis and interpretation of textual interview data.

We used Nvivo 8 for that purpose. Attributes were used within NVivo to organise 
company and interviewee characteristics. The relationship among the emerging themes was reviewed and discussed in the findings section.

Verbatim quotations offer readers greater depth of understanding, as words show the strength of the participants' views. As other authors (Graebner, 2009) do, we presented verbatim illustrative quotes as findings that are classified into different dimensions and facilitate the understanding of the case. The names of the interview participants were anonymized for confidentiality purposes. A summary of the characteristics of the interviewees is seen in Appendix (1) and a summary of participant firms is presented in Appendix (2).

\section{FINDINGS}

This case shows that foreign firms can use COCs as a location strategy of their FDI because the manager assigned to that setting can find a community of expatriates that provide business and social value. The expatriates from the different subsidiaries located in the business park that shared a common culture and background were able to create a community of practice that helped them share information, knowledge and practices about how to do business in China.

From the analysis of the codes and categories we summarize the main findings in table 1.

\section{The structural dimension}

Regarding, the network ties, although they are all industrial manufacturing firms, they do not compete against each other as their activities differ from each other. This increases trust and allows the exchange of more diverse knowledge, which could reduce the lockin risk. Even if there are co-located firms from the same sector, the knowledge is transmitted easily through companies, especially from experienced companies. However, the lack of complementarity in their activities could restrict or limit their joint activities and inter-firm cooperation (i.e. joint logistics, purchasing, etc.). The value or richness of the exchange is mainly influenced by the years of experience of the companies, their size 
or the experience in the park, as well as by the similarity among the expatriates (in terms of age or interests).

In line with Wenger et al. (2002), we note that expatriates have very frequent interaction and contact where they share both personal and professional issues. They get together every day in the "expat canteen". Contact by telephone or email is also frequent but a significant importance is given to the face-to-face interaction at lunch time. There are diverse factors influencing "who you talk to" in the park. Some make reference to company characteristics and some to manager characteristics. As the park has been expanding the relationships among the expatriates have also changed over time.

It is remarkable that firms do not consider the geographical proximity to their clients, suppliers, etc. (business rationale) as the primary location factor. In fact, the organizational proximity (other firms from the same business group) is what motivated them to locate there. The geographical and organizational proximity in the home country influences their co-location in the host country.

In terms of the network configuration, the findings suggest that the role of the General Service Company of the park (A1) is key on the management of the cluster and the promotion of the interaction among the subsidiary firms (facilitator and mediator of the network). The house where A1 has its offices represents a typical rural Basque cottage. It also has the restaurant where the managers have lunch, meeting rooms and guest rooms for visitors. However, there can be divergent views from the agglomeration firms in respect to how effective the leading role is by the general service firm, no matter if the firm was a first-mover (A7) or not (A12), medium size (A9) or small (A4).

The park has a semi-open membership nature, as they do not accommodate joint ventures and they prioritize investments from the Basque Country. Although since its creation 2 
firms have closed down their activities, the member subsidiaries believe there is stability on the network. What it is a big concern for them is the rotation levels of the employees. To avoid this, they have some "gentlemen agreements": non- aggression policy (not to hire others' workers) and transparency (to share how much they pay to the workers or information about reliable suppliers). There have also been attempts to standardize their labour "handbooks" (timetables, wages, etc.) and some companies commented that they are thinking to create a pension plan for workers.

\section{The cognitive dimension}

There are different subgroups in the cluster, depending on the entry date to the cluster, and over time, as the park has been expanding, the relationships among the expatriates have also changed. The resources, knowledge and legitimacy that arise from adding new members to the $\mathrm{CoP}$ become redundant. Some managers argue that "community" and a "collective" exists at the individual level among expatriates but that this identity is not expanded to local employees so there are different view about the collective identity of the park as a whole. However, there was a deliberate attempt from some expatriates to include the local workers in the course of claiming 'who' should be part of the collective identity.

Although the goals of the cluster are not explicit and its subsidiary is autonomous and has its own business goals, the managers believe that implicit cluster goals are related to the management style of the subsidiaries in China, to acquire market knowledge, find synergies and develop a common image and lobby strength. Being that many of the firms are cooperative enterprises in their home country, a debate exists concerning whether they are implementing their cooperative management principles and values in the subsidiaries. Subsidiary managers try to increase the workers' participation and involvement in 
discussions and decisions but these cultural differences (mainly the concept of power distance) limit this type of interaction. As they argue, there is no understanding of the Chinese workers of such a participative model.

The expatriates try to organize social activities (i.e. sports day) that help them to share and having a common culture among the workers from different subsidiaries. However, some companies think that they could do more in this regard. Basque-Chinese cultural icons and symbols are present in the cluster (Basque Cottage as central office, flags, paintings, etc.). The cluster and the $\mathrm{CoP}$ is used by the managers not only to share information about the local market but to maintain a feeling of belonging to the home country, which is seen by some as a barrier for the adaptation and attachment to the local context and culture.

\section{The relational dimension}

The park helps to have a frequent interaction that builds trust among expatriates and enables the managers to share their concerns in a reciprocal way and find solutions for their daily problems. The global economic situation has affected the firms as their priority is to maintain and sustain their own business goals, but the agglomerated firms perceive that they need to strengthen the role of the park and increase the synergies among the firms in the future.

Guanxi was often addressed by the expatriates as one of the key cultural values which they regarded as essential for them to adapt to in the course of interacting with external agents and gaining legitimacy in the host country, especially when it comes to building relationships with the local government. In line with Park and Luo (2001) they recognize that guanxi could be relevant to secure favours at a personal level. They link it with the instrumental dimension of the concept (Su et al., 2009), although they also relate it to 
corruption. This could be in line with what Graeff (2009) calls the dark side of social capital. The general service company tries to develop guanxi network with local institutions and acts as a representative for the rest of the park members. However, firms have different views on how effective this service is. This heterogeneous value could be due to the experience of the firms in Kunshan.

\section{The value of COC and its use: other determining factors}

In this point, it is important to emphasize other results that we obtained from the analysis and allow us triangulate the information obtained (Maxwell, 2005). We have checked if the demographic characteristics of the interviewees have influenced their perceptions about the ISC and the CoP. In general we can say elements such as the educational background or age did not influence the differences of the responses, while other elements related to the experience could have some effect on the expatriates' perceptions. This resonates with other lines of research that relate the experience with the entry mode and establishment decision in distant markets (Wu et al., 2017; Shen and Puig, 2018). Thus, we can assert that the ISC has a vast importance for those expatriates that have less experience in the host country. In fact, the structural dimension (their ties and in particular the role of the general service company) is especially important in the first stages of the firms in China, while how the ISC is used is more influenced by cognitive or relational dimensions.

This study provides evidence that the presence of ethnic communities of practice influence the location choices of multinationals. However, a heterogeneity exists when it comes to the development and use of the social capital generated by the expatriate members of that community. Our findings show that the level of synergy and use of the expatriate community of practice in the COC depends on organizational level factors such 
as the entry date and the similarity of business activity, their competitive relationships, their size or their organizational linkages in the home country. Besides, other individual level factors such as the personal linkages among expatriates, the time they spend together in social gatherings or the previous experience they have in the host country also influence its use. Looking at the structural element of the community, the identification of a leader and facilitator of the network has been identified as a key element in the success of the network. 
Table 1: Summary of the findings

\begin{tabular}{|c|c|c|c|}
\hline $\begin{array}{l}\text { Theoretical } \\
\text { dimension }\end{array}$ & $\begin{array}{c}\text { Theoretical } \\
\text { category }\end{array}$ & Findings & Selection of quotes \\
\hline \multirow[t]{3}{*}{$\begin{array}{c}\text { Structural } \\
\text { dimension } \\
\text { of social } \\
\text { capital }\end{array}$} & Network ties & $\begin{array}{l}\text { - Heterogeneity and multisectoriality } \\
\text { (potential towards automotive) adds value } \\
\text { but limits cooperation } \\
\text { - The power of face-to-face interaction } \\
\text { (daily) emphasized as a mean to share } \\
\text { problems } \\
\text { - The geographical and organizational } \\
\text { proximity in the home country influenced } \\
\text { their co-location strategy in China. } \\
\text { - The interaction depends on: size of the } \\
\text { company, historical reasons, personal } \\
\text { links, experience in the host country } \\
\text { - Similarity of members (age, interest, etc.) } \\
\text { fosters a more frequent interaction }\end{array}$ & $\begin{array}{l}\text { "The trust is higher because we are not competing" (A7R1, 2013). } \\
\text { "The fact of going for lunch every day, the fact of being close... facilitates the face-to- } \\
\text { face contact every week [...] the face-to-face that I think it's important" (A12R1, 2013). } \\
\text { "For us the best place regarding proximity to clients and suppliers was Guangdong } \\
\text { province. However, we decided to come to Kunshan be with other companies from } \\
\text { Mondragon so as to benefit from the synergies, to share our experiences, to avoid } \\
\text { management errors and of course to make friends and be motivated" (A7R1, 2013). } \\
\text { "I meet more frequently the companies that have the same suppliers or with those that } \\
\text { arrived at the same time as we did" (A11R1, 2013). } \\
\text { "The interaction with members depends on the size of the company, historical reasons } \\
\text { because we belong to the same division, and also because of personal linkages" (A4R1, } \\
2013 \text { ). }\end{array}$ \\
\hline & $\begin{array}{c}\text { Network } \\
\text { configuration }\end{array}$ & $\begin{array}{l}\text { Divergent views on the leading and } \\
\text { representative role of the General Service } \\
\text { Company A1. Lack of commitment and } \\
\text { continuity is critized } \\
\text { - Semi- open membership nature: no JVs, } \\
\text { priority COO }\end{array}$ & $\begin{array}{l}\text { "For the establishment process I think it was good in the beginning. Because you know, } \\
\text { the relationship with the local government is not so easy, so it helps a lot" (A3R1, 2013)" } \\
\text { "In the beginning it helps, in the beginning it helps [...] I am thinking mainly about } \\
\text { government, country and barriers" (A10R1, 2013). } \\
\text { "We do not need someone who coordinates but we need a leader. The person who is in } \\
\text { charge of general services" (A8R1, 2013). } \\
\text { "General Services Company is not leading anything; they react. If we have something, we } \\
\text { ask then and they do it, but they are not leading" (A11R1, 2013) }\end{array}$ \\
\hline & $\begin{array}{c}\text { Network } \\
\text { stability }\end{array}$ & $\begin{array}{l}\text { - Since its creation } 2 \text { firms closed } \\
\text { - One of their main challenges is employee } \\
\text { rotation } \\
\text { - Non-written agreement not to affect other } \\
\text { firms when recruiting and establishing } \\
\text { salary levels }\end{array}$ & $\begin{array}{l}\text { "If there was a leadership and some norms, then the salaries could have been standardized } \\
\text { but anyway, they are more standard than what we think" (A7R1, 2013) } \\
\text { "I think that there is stability. Maybe the only thing that could affect us is the rotation of } \\
\text { people. That is one of the problems as the knowledge is on the people" (A11R1, 2013) }\end{array}$ \\
\hline
\end{tabular}




\begin{tabular}{|c|c|c|c|}
\hline \multirow[t]{3}{*}{$\begin{array}{l}\text { Cognitive } \\
\text { dimension } \\
\text { of social } \\
\text { capital }\end{array}$} & $\begin{array}{c}\text { Social } \\
\text { cohesion }\end{array}$ & $\begin{array}{l}\text { - Different subgroups are evident depending } \\
\text { on the entry date of the firms } \\
\text { - Community is mainly considered as } \\
\text { expatriates' community }\end{array}$ & $\begin{array}{l}\text { Field notes: They called themselves G4, G3 as the first } 4 \text { companies, the } 3 \text { that came later. } \\
\text { "When I say people I say expats" (A7R1, 2013) } \\
\text { "It is collective with us [just expats] not collective with the local people" (A12R1, 2013) } \\
\text { "I guess the direct workers are more sensitive and will say that they don't have that } \\
\text { collective identity. The Chinese workers do not officially meet other Chinese workers } \\
\text { from other companies but sometimes it happens that through us I ask another manager } \\
\text { about for example accountancy, purchasing... and we put our workers in contact for some } \\
\text { issues" (A12R1, 2013). }\end{array}$ \\
\hline & $\begin{array}{l}\text { Congruence } \\
\text { level }\end{array}$ & $\begin{array}{l}\text { - Business goals are individual. They do not } \\
\text { define any explicit share goals, mission or } \\
\text { values } \\
\text { - Contrasting views about the unity of the } \\
\text { members as working as a collective (rather } \\
\text { as individual firms) } \\
\text { - Debate about the implementation of } \\
\text { cooperative management principles and } \\
\text { values in subsidiaries }\end{array}$ & $\begin{array}{l}\text { "Each company has some economic goals [but] we all have similar management models } \\
\text { and styles in our headquarters, we all try to approach similarly our subsidiaries here in } \\
\text { China" (A9R1,2013). } \\
\text { "We have individual goals but I suppose that all [...] want to have an space in the Chinese } \\
\text { market, know about the Chinese market [...]" (A2R1, 2013). } \\
\text { "The idea is that of finding synergies, create a common image, expand our size and } \\
\text { develop lobby strength" (A1R1, 2013). } \\
\text { "We know what is a cooperative, we know the values but I don't think my workers have } \\
\text { this perception" (A11R1, 2013) } \\
\text { "We are trying to involve them [workers] but it is not easy because they are not used to } \\
\text { it. In the Chinese culture they are used to have a boss, the boss makes the decisions and } \\
\text { he is right, there is no discussion about it if it is right or it is wrong and this is the most } \\
\text { difficult problem I have" (A3R1, 2013). }\end{array}$ \\
\hline & $\begin{array}{l}\text { Feeling of } \\
\text { belonging }\end{array}$ & $\begin{array}{l}\text { - They organize common social activities } \\
\text { that help sharing and having a common } \\
\text { culture among workers } \\
\text { - Common language and home country } \\
\text { culture emphasized as characterising } \\
\text { elements } \\
\text { - Cultural icons and symbols evident } \\
\text { - Agglomeration as the space to keep the } \\
\text { home country belongingness feeling } \\
\text { - Expatriates "we-ness" as a barrier for the } \\
\text { adaptation and attachment to the local } \\
\text { context }\end{array}$ & $\begin{array}{l}\text { "The sport day is helpful to share a culture among the workers." (A11R1, 2013) } \\
\text { "As a park we also organize the sport meeting day every year and English and Chinese } \\
\text { lessons, but the potential for this is much higher" (A4R1, 2013). } \\
\text { "With activities such as the sport day and the Korrika (gatherings that are typical in the } \\
\text { Basque Country, for social or cultural reasons) where all companies and workers } \\
\text { participate we develop a bit of that sense of common we-ness and that we are not here } \\
\text { alone" (A12R1, 2013) } \\
\text { "Yes we have a logo in the gates. People identify with that" (A6R1, 2013). } \\
\text { "To have those Spanish firms located near you, a linkage with 'home' [...] is a big } \\
\text { motivation" (A12R1, 2013) } \\
\text { "Proximity matters. To go for lunch together and being able to 'get out of China' for an } \\
\text { hour and feel you are at home with your friends has a lot of value. I have been here } 7 \\
\text { years and I know what I am talking about" (A8R1, 2013). }\end{array}$ \\
\hline
\end{tabular}




\begin{tabular}{|c|c|c|c|}
\hline & & & $\begin{array}{l}\text { "I got that knowledge because of experience, and because of being here in the cluster. } \\
\text { [...]. If someone asks about Chinese guanxi or Chinese culture, she/he will understand } \\
\text { better from me than from a Chinese" (A8R1, 2013) } \\
\text { "It (the community of expats) has an opposite effect that makes you adapt less to the } \\
\text { culture" (A3R1, 2013) }\end{array}$ \\
\hline \multirow[t]{3}{*}{$\begin{array}{l}\text { Relational } \\
\text { dimension } \\
\text { of social } \\
\text { capital }\end{array}$} & $\begin{array}{l}\text { Trust and } \\
\text { reliability }\end{array}$ & $\begin{array}{l}\text { - Enforced by cultural and physical } \\
\text { closeness, connections in the home } \\
\text { country and friendly environment among } \\
\text { expats as an element of lowering } \\
\text { - Trust as an costs }\end{array}$ & $\begin{array}{l}\text { "The point is that when you trust others you feel confidence to say what you think and put } \\
\text { forward your opinion. The direct contact fosters that trust" (A12R1, 2013) } \\
\text { "For example to prepare the due diligence }[\ldots] \text { when a company in the park has used one } \\
\text { provider and tells me, I just take that and the transaction cost is zero" (A7R1, 2013) }\end{array}$ \\
\hline & Commitment & $\begin{array}{l}\text { - Willingness and commitment to help each } \\
\text { other on their daily problems } \\
\text { - Commitment to the development of the } \\
\text { collective is reduced by the business } \\
\text { pressures, HQ's goals and time limitations }\end{array}$ & $\begin{array}{l}\text { "When you arrive into China you have a lot of problems and everybody here is ready to } \\
\text { help }[\ldots] \text { You ask the rest of the managers: has somebody had the same problem? How } \\
\text { have you solved in the past?" (A3R1,2013) } \\
\text { "We are busy with our business [...] we have no time" (A11R1, 2013). } \\
\text { "We need to tight our belt so we have very strict targets this year. We are not thinking } \\
\text { about making any expense or putting any resource or further involvement [on the CoP]" } \\
\text { (A8R1, 2013) }\end{array}$ \\
\hline & $\begin{array}{l}\text { Networks } \\
\text { and guanxi }\end{array}$ & $\begin{array}{l}\text { - Guanxi is mainly associated to } \\
\text { government ties and lobby. Other } \\
\text { associations include corruption and } \\
\text { relationships among expatriates } \\
\text { - Service company as leader and } \\
\text { representative who builds guanxi network } \\
\text { for all the members } \\
\text { - Guanxi is seen as an element that } \\
\text { facilitates business and gaining legitimacy } \\
\text { - The community in the park helps them } \\
\text { extent their networks and create synergies. }\end{array}$ & $\begin{array}{l}\text { "What helps is the lobby. We had a problem during the construction and as a result of } \\
\text { being so many companies here and developing the process through the general service } \\
\text { company (A1) they [government] removed us the fine, and that was not little money" } \\
\text { (A12R1, 2013). } \\
\text { "It is due to these good relationships with the government that we managed to agree a } \\
\text { fixed and cheaper price of the land" (A1R1, 2013). } \\
\text { "Guanxi is also between general managers, expat people [...] but when we talk about } \\
\text { guanxi, we talk about how to influence somebody to make something for us. [...] Guanxi } \\
\text { is always talking about corruption [...] it is very difficult to manage. [...]. We have been } \\
\text { working a lot to get knowledge about how to achieve local host country legitimacy, the } \\
\text { guanxi, the quality reputation and the price reputation" (A3R1, 2013). } \\
\text { "We have A1 that is very good at dealing with institutions" (A9R1, 2013) } \\
\text { "From my point of view there is nobody strong enough. I don't think anyone from } \\
\text { General Services [A1] can have a meeting with everyone from the government on behalf } \\
\text { of Mondragon" (A7R1, 2013). }\end{array}$ \\
\hline
\end{tabular}




\begin{tabular}{|l|l|l|}
\hline & & $\begin{array}{l}\text { "It's normal to extend our connections here. If other firms keep working and growing the } \\
\text { business, it is normal for them to grow their network so yes, we extend the network with } \\
\text { clients, distributors, government, etc. (A8, 2013). } \\
\text { "For us the best place regarding proximity to clients and suppliers was Guangdong } \\
\text { province. However, we decided to come to Kunshan be with other companies from } \\
\text { MONDRAGON so as to benefit from the synergies, to share our experiences, to avoid } \\
\text { management errors and of course to make friends and be motivated" (A7, 2013). }\end{array}$ \\
\hline
\end{tabular}

Source: own elaboration 


\section{DISCUSSION AND CONCLUSION}

In this paper, we analyse the international social capital (ISC) in the COC. The paper adopts a qualitative methodological approach through an inductive case study developed with 13 managers to look for patterns and describe the relationships among the expatriates of Spanish companies co-located in Mondragon Kunshan Industrial Park based in Jiangsu, China. By focusing our research in China we recognize the importance of clustering when doing business in distant markets. As opposed to other research, our work goes beyond the study of the reasons and effect of co-locating FDI and enables us to understand how the international social capital is created and exploited in this emerging market.

We can affirm that the ISC is dynamically constructed by expatriates, whose interaction contribute not only to their psychological wellbeing and trust building but also to support firms to gain legitimacy in emerging markets. The ISC generated in the CoP of expatriates gives the members access to resources, information and opportunities. Moreover, we have observed that this ISC is constructed differently depending on the length of the relationships (establishment/ arrival date), the nature of the relationship (business related or not), the size of the firms (with resources), historical linkages of the firms or the years of experience of the managers in the host country. Besides, we found that when ISC is just developed among expatriates, this could hinder their integration and cultural adaptation. It is also important to mention that our analysis shows that both the countryof-origin culture and the existence of a leader firm in the park are crucial facilitators for the community construction and development of ISC within the COC.

Specifically, our work contributes towards explaining the mechanisms about how this ISC is created and used among expats. The common location and place of FDI firms in a 
COC fosters the kind of interactions and trust needed to create the local knowledge (suppliers, regulations, recruitment) that helps to increase firms' negotiation power and to reduce transaction costs. Moreover, our research shows that the value of this ISC is more important in the first stages of establishment in the country, and for managers with less experience or no previous connexions there.

These findings have two important contributions: 1) it explains why, despite the fact that they are part of the same set of institutions in the host and home country, some firms locate outside clusters and those within COCs are not equally connected to local networks and perform differently; and 2) it helps firms to better guide and direct their international assignments and evaluate the roles and competences (i.e. clustering competences) that these expatriates should have (Lakshman and Lakshman, 2017). It is important for managers of firms going to emerging countries, that the development of ISC within geographical COCs can help them in their internationalization but that the way they can maximize its benefits could be heterogeneous.

This paper has several limitations which future research may overcome. First, the sample of firms was drawn from only one country, China. Although by focusing on a single country we can control for the effects of different institutional environments affecting this relationship (Criscuolo \& Narula, 2008), one should not generalize the implications of our findings without examining the particular cultural characteristics of those contexts. Second, we focus on the phenomena of clusters but no other geographical realities such as the global cities. An extension of our study could be linked to those realities (Goerzen et al., 2013). Third, it could also be interesting to study whether this location model can serve as a springboard for development in other emergent markets and for other FDI (i.e. Multilatinas) and if it can serve to overcome other liabilities such as that of emerginness (Madhok and Keyhani, 2012). Moreover, we believe that future research should focus on 
the local network by collecting data from local employees and considering the interrelationship with the local employees and the local community, as well as the subsidiaries embeddedness in the local setting. Another line of research could be linked to the role of the subsidiary and its autonomy and how this can influence the mechanisms through which the ISC is developed in the host country. Our research could form the basis to further analyse the expatriates' boundary-spanning role, and its effect on the international social capital of the organizations and the future development and survival chances of their subsidiaries.

\section{REFERENCES}

Ács, Z. J., Szerb, L., Ortega-Argilés, R., Aidis, R., \& Coduras, A. (2015). The regional application of the global entrepreneurship and development index (GEDI): the case of Spain. Regional Studies, 49(12), 1977-1994.

Adler, P. S., \& Kwon, S. W. (2002). Social capital: Prospects for a new concept. Academy of management review, 27(1), 17-40.

Alcacer, J., \& Chung, W. (2014). Location strategies for agglomeration economies. Strategic Management Journal, 35(12), 1749-1761.

Alfaro, L., \& Chen, M. X. (2014). The global agglomeration of multinational firms. Journal of International Economics, 94(2), 263-276.

Allee, V. (2000). Knowledge networks and communities of practice. OD practitioner, 32(4), 4-13.

Anderson, W. P. (2012). Economic geography. Routledge.

Au, K. Y., \& Fukuda, J. (2002). Boundary spanning behaviors of expatriates. Journal of World Business, 37(4), 285-296.

Barner-Rasmussen, W., Ehrnrooth, M., Koveshnikov, A., \& Mäkelä, K. (2014). Cultural and language skills as resources for boundary spanning within the MNC. Journal of International Business Studies, 45(7), 886-905.

Beugelsdijk, S., McCann, P., \& Mudambi, R. (2010). Introduction: Place, space and organization - economic geography and the multinational enterprise. Journal of Economic Geography, 10(4), 485-493.

Birkinshaw, J., Brannen, M. Y., \& Tung, R. L. (2011). From a distance and generalizable to up close and grounded: Reclaiming a place for qualitative methods in international business research. Journal of International Business Studies, 42(5), 573-581.

Brown, J., \& Duguid, P. (2000). Organizational learning and communities of practice: Toward a unified view of working, learning, and innovation. In Knowledge and communities (pp. 99-121). 
Buckley, P. J., \& Carter, M. J. (2002). Process and structure in knowledge management practices of British and US multinational enterprises. Journal of International Management, 8, 29-48.

Burt, R. S. (2002). The social capital of structural holes. The new economic sociology: Developments in an emerging field, 148-190.

Chen, H., \& Chen, T. J. (1998). Network linkages and location choice in foreign direct investment. Journal of international business studies, 445-467.

Chetty, S. \& Blankenburg Holm, D. (2000). Internationalisation of small to medium-size manufacturing firms: a network approach, International Business Review, 9, 77-93.

Chu, M. T., Khosla, R. \& Nishida, T. (2012). Communities of practice model driven knowledge management in multinational knowledge based enterprises. Journal of Intelligent Manufacturing, 23(5), 1707-1720.

Chung, S., Singh, H., and Lee, K. (2000). Complementarity, status similarity and social capital as drivers of alliance formation. Strategic management journal, 1-22.

Coleman, J. S. (1988). Social capital in the creation of human capital. American journal of sociology, S95-S120.

Coviello, N. E. (2006). The network dynamics of international new ventures. Journal of International Business Studies, 37(5), 713-731.

Cox, A. (2005). What are communities of practice? A comparative review of four seminal works. Journal of information science, 31(6), 527-540.

Creswell, J. W. (1997). Qualitative Inquiry and Research Design: Choosing among Five Traditions, London: Sage Publications

Criscuolo, P., \& Narula, R. (2008). A novel approach to national technological accumulation and absorptive capacity: aggregating Cohen and Levinthal. The European Journal of Development Research, 20(1), 56-73.

Cummings, S. \& Van Zee, A. (2005). Communities of practice and networks: reviewing two perspectives on social learning. Knowledge Management for Development Journal, 1(1), 8-22.

De Propris L. \& Driffield N. (2006). FDI, clusters and knowledge sourcing. In: C. Pitelis, R. Sugden and J.R. Wilson, eds. Clusters and globalisation: The development of urban and regional economies. Cheltenham: Edward Elgar Publishing Inc, pp. 133158.

Doz, Y. (2011). Qualitative research for international business. Journal of International Business Studies, 42(5), 582-590.

Dunning, J. H. (2009). Location and the multinational enterprise: A neglected factor?, Journal of International Business Studies, 40(1), 5-19.

Eisenhardt, K. M. (1989). Building theories from case study research. Academy of management review, 14(4), 532-550.

EJ-GV (1999). La actitud emprendedora en la CAPV. Kualitate Lantaldea. Servicio Central de Publicaciones del Gobierno Vasco.

Ellis, P., \& Pecotich, A. (2001). Finding international exchange partners: the role of social ties. Global Focus, 13(2), 121-134. 
Feldman, D. C., \& Bolino, M. C. (1999). The impact of on-site mentoring on expatriate socialization: A structural equation modelling approach. International Journal of Human Resource Management, 10(1), 54-71.

Freeman, S., Daniel, L. J., \& Murad, W. (2012). Knowledge and network development for service firm entry into emerging Asian markets. Asian Business \& Management, 11(1), 101-122.

Freeman, S., Hutchings, K., Lazaris, M., \& Zyngier, S. (2010). A model of rapid knowledge development: The smaller born-global firm. International Business Review, 19 (1), 70-84.

Garavan, T. N., Carbery, R., \& Rock, A. (2012). Mapping talent development: definition, scope and architecture. European Journal of Training and Development, 36(1), 5-24.

García-Cabrera, A. M., and García-Soto, M. G. (2017). Quality of the environment and SME's internationalisation: A regional analysis in Spain. Emprendimiento $y$ Negocios Internacionales, 1(1), 11-18.

García-Villaverde, P. M., Parra-Requena, G., \& Molina-Morales, F. X. (2017). Structural social capital and knowledge acquisition: implications of cluster membership. Entrepreneurship \& Regional Development, 1-32.

Ghauri, P. N. \& Grønhaug, K. (2005). Research methods in business studies: A practical guide. Pearson Education.

Gioia, D. A., Corley, K. G., \& Hamilton, A. L. (2013). Seeking qualitative rigor in inductive research notes on the gioia methodology. Organizational Research Methods, 16(1), 15-31.

Gnyawali, D. R., and Singal, M. (2009). Knowledge ties among subsidiaries in MNCs: A multi-level conceptual model. Journal of International Management, 15(4), 387-400.

Goerzen, A., Asmussen, C. G., \& Nielsen, B. B. (2013). Global cities and multinational enterprise location strategy. Journal of international business studies, 44(5), 427450.

Gooderham, P. N. (2007). Enhancing knowledge transfer in multinational corporations: a dynamic capabilities driven model. Knowledge management research \& practice, 5(1), 34-43.

Graebner, M. E. (2009). Caveat venditor: Trust asymmetries in acquisitions of entrepreneurial firms. Academy of Management Journal, 52(3), 435-472.

Graeff, P. (2009). Social capital: the dark side. Edward Elgar.

Guercini, S., Dei Ottati, G., Baldassar, L. \& Johanson, G. (2017). Liabilities of Native and Immigrant Entrepreneurship in the Processes of Globalization. In Native and Immigrant Entrepreneurship (pp. 7-29). Springer International Publishing.

Haghirian, P. (2006). International Knowledge Transfer as a challenge for Communities of Practice. In Clarke S. (Ed.), Encyclopedia of Communities of Practice in Information and Knowledge Management. (pp. 239-245), Hershey PA: Idea Group.

Håkansson, H., and Johanson, J. (1993). The network as a governance structure: interfirm cooperation beyond markets and hierarchies. Univ.

Hardy, C., Lawrence, T. B., and Grant, D. (2005). Discourse and collaboration: The role of conversations and collective identity. Academy of management review, 30(1), 5877. 
Harris, S. \& Wheeler, C. (2005). Entrepreneurs' relationships for internationalization: functions, origins and strategies. International business review, 14(2), 187-207.

He, C., Wei, Y. D. and Pan, F. (2007). Geographical concentration of manufacturing industries in China: The importance of spatial and industrial scales. Eurasian Geography and Economics, 48(5), 603-625.

Huberman, A. M. \& Miles, M. B. (1994). Data management and analysis methods. Sage Publications.

Hubert, C., Newhouse, B. \& Vestal, W. (2001). Building and sustaining communities of practice. Houston: American Productivity Centre.

Hymer, S. H. (1960). The international operation of national firms: A study of direct foreign investment. Doctoral dissertation, Massachusetts Institute of Technology.

Inkpen, A.C. \& Tsang, E. W. K., (2005). Social Capital, Networks, and Knowledge Transfer. The Academy of Management Review, 30 (1), 146-165.

Jacobs, J. (1961). The Death and Life of Great American Cities. Vintage.

Jain, N. K., Kothari, T., \& Kumar, V. (2016). Location choice research: Proposing new agenda. Management International Review, 56(3), 303-324.

Johanson, J. \& Vahlne, J.-E. (2009). The Uppsala in internationalization process model revisited: From liability of foreignness to liability of outsidership. Journal of International Business Studies, 40 (9), 1411-31.

Johnson, K. L., \& Duxbury, L. (2010). The view from the field: A case study of the expatriate boundary-spanning role. Journal of World Business, 45(1), 29-40.

Johnstone, H., \& Lionais, D. (2004). Depleted communities and community business entrepreneurship: revaluing space through place. Entrepreneurship \& Regional Development, 16(3), 217-233.

Jones, J. (2017). Agglomeration economies and the location of foreign direct investment: A meta-analysis. Journal of Regional Science, 57(5), 731-757.

Kim, J. U., \& Aguilera, R. V. (2016). Foreign location choice: Review and extensions. International Journal of Management Reviews, 18(2), 133-159.

Kogut, B., \& Zander, U. (1993). Knowledge of the Firm and the Evolutionary Theory of the Multinational Corporation. Journal of International Business Studies, 24 (4), 625 645 .

Kostova, T. \& Roth, K. (2002). Adoption of an organizational practice by subsidiaries of multinational corporations: Institutional and relational effects. Academy of management journal, 45(1), 215-233.

Lakshman, S., \& Lakshman, C. (2017). The dynamic change in expatriate roles: strategy type and stage of internationalization. Management Decision, 55(8), 1770-1784.

Lave, J. \& Wenger, E. (1991). Situated learning: Legitimate peripheral participation (Vol. 521423740). Cambridge: Cambridge university press.

Lesser, E. L., \& Storck, J. (2001). Communities of practice and organizational performance. IBM systems journal, 40(4), 831.

Lesser, E., \& Prusak, L. (1999). Communities of practice, social capital and organizational knowledge. Information Systems Review, 1(1), 3-10. 
Liao, T. J., and Yu, C. M. J. (2012). Knowledge transfer, regulatory support, legitimacy, and financial performance: The case of foreign firms investing in China. Journal of World Business, 47(1), 114-122.

Lin, N. (1999). Building a network theory of social capital. Connections, 22(1), 28-51.

Lindstrand, A., Melen, S. \& Nordman, E. (2011). Turning social capital into business: A study of the internationalization, International Business Review, 20 (2) 194-212.

Lui, S. S. (2009). The Roles of Competence Trust, Formal Contract, and Time Horizon in Interorganizational Learning. Organization Studies, 30 (4).

Madhok, A., \& Keyhani, M. (2012). Acquisitions as entrepreneurship: Asymmetries, opportunities, and the internationalization of multinationals from emerging economies. Global Strategy Journal, 2(1), 26-40.

Mariotti, S., Piscitello, L. \& Elia, S. (2010). Spatial agglomeration of multinational enterprises: the role of information externalities and knowledge spillovers. Journal of Economic Geography, 10(4), 519-538.

Masciarelli, F. (2011). The strategic value of social capital: How firms capitalize on social assets. Edward Elgar Publishing.

Maurer, I. \& Ebers, M. (2006). Dynamics of social capital and their performance implications: Lessons from biotechnology start-ups. Administrative Science Quarterly, 51 (2), 262-292.

Maxwell, J. A. (2005). Qualitative research design, an interactive approach (2a ed.). USA: Sage Publications.

McDonald, C., Buckley, P. J., Voss, H., Cross, A. R., \& Chen, L. (2018). Place, space, and foreign direct investment into peripheral cities. International Business Review.

Mesquita, L. F., \& Lazzarini, S. G. (2008). Horizontal and vertical relationships in developing economies: Implications for SMEs' access to global markets. Academy of Management Journal, 51(2), 359-380.

Mondragon (2017). Annual report 2016. Available from: www.mondragoncorporation.com

Nahapiet, J. \& Ghoshal, S. (1998). Social capital, intellectual capital, and the organizational advantage. Academy of Management Review, 23 (2).

Nicholson, J., Gimmon, E., \& Felzensztein, C. (2017). Economic geography and business networks: creating a dialogue between disciplines: An introduction to the special issue. Industrial Marketing Management, 61, 4-9.

Nielsen, B. B., Asmussen, C. G. \& Weatherall, C. D. (2017). The location choice of foreign direct investments: Empirical evidence and methodological challenges. Journal of World Business, 52(1), 62-82.

Noorderhaven, N., \& Harzing, A. W. (2009). Knowledge-sharing and social interaction within MNEs. Journal of International Business Studies, 40(5), 719-741.

Opper, S., \& Nee, V. (2015). Network effects, cooperation and entrepreneurial innovation in China. Asian Business \& Management, 14(4), 283-302.

Oviatt, B. M. \& McDougall, P. P. (2005). Defining international entrepreneurship and modeling the speed of internationalization. Entrepreneurship theory and practice, 29(5), 537-554.

Park, S. H. \& Luo, Y. (2001). Guanxi and organizational dynamics: Organizational networking in Chinese firms. Strategic management journal, 22(5), 455-477. 
Partanen, J., Möller, K., Westerlund, M., Rajala, R. \& Rajala, A. (2008). Social capital in the growth of science-and-technology-based SMEs. Industrial Marketing Management, 37(5), 513-522.

Pattinson, S. \& Preece, D. (2014). Communities of practice, knowledge acquisition and innovation: a case study of science-based SMEs. Journal of Knowledge Management, 18(1), 107-120.

Paul, J., S. Parthasarathy, \& P. Gupta (2017). Exporting Challenges of SMEs: A Review and Future Research Agenda. Journal of World Business, 52(3),327-342

Peng, M. \& Meyer, K. (2011). International Business. Cengage Learning EMEA: London.

Peng, M. W. \& Luo, Y. (2000). Managerial ties and firm performance in a transition economy: The nature of a micro-macro link. Academy of management journal, 43(3), 486-501.

Peng, M. W., Wang, D. Y. L., \& Jiang, Y. (2008). An institution-based view of international business strategy: a focus on emerging economies. Journal of International Business Studies, 39 (5), 920-36.

Putnam, R. D. (1995). Bowling alone: America's declining social capital. Journal of democracy, 6(1), 65-78.

Raab, K. J., Ambos, B., \& Tallman, S. (2014). Strong or invisible hands?-Managerial involvement in the knowledge sharing process of globally dispersed knowledge groups. Journal of World Business, 49(1), 32-41.

Sharma, D. D. \& Blomstermo, A. (2003). The internationalization process of born globals: a network view. International business review, 12(6), 739-753.

Shen, Z., \& Puig, F. (2018). Spatial dependence of the FDI entry mode decision: Empirical evidence from emerging market enterprises. Management International Review, 1-23.

Sinkovics, R. R., Penz, E. \& Ghauri, P. N. (2008). Enhancing the trustworthiness of qualitative research in international business. Management International Review, 48(6), 689-714.

Smale, A., Björkman, I., Ehrnrooth, M., John, S., Mäkelä, K., \& Sumelius, J. (2015). Dual values-based organizational identification in MNC subsidiaries: A multilevel study. Journal of International Business Studies, 46(7), 761-783.

Stallkamp, M., Pinkham, B. C., Schotter, A. P. \& Buchel, O. (2017) Core or periphery? The effects of country-of-origin agglomerations on the within-country expansion of MNEs. Journal of International Business Studies 1-25.

Su, C., Yang, Z., Zhuang, G., Zhou, N. \& Dou, W. (2009). Interpersonal influence as an alternative channel communication behavior in emerging markets: The case of China. Journal of International Business Studies 40 (4), 668-689.

Susman, G. I. (Ed.). (2007). Small and medium-sized enterprises and the global economy. Edward Elgar Publishing.

Tallman, S. \& Chacar, A. S. (2011). Knowledge accumulation and dissemination in MNEs: a practice-based framework. Journal of Management Studies, 48(2), 278-304. 
Tan, D. \& Meyer, K. E. (2011). Country-of-origin and industry FDI agglomeration of foreign investors in an emerging economy. Journal of International Business Studies, 42 (4), 504-20.

Thomas, D. (1994). The boundary-spanning role of expatriates in the multinational corporation. Advances in International Comparative Management, 9: 145-170.

Tsai, W. \& Ghoshal, S. (1998). Social Capital and Value Creation: The Role of Intrafirm Networks. The Academy of Management Journal, 41 (4).

Tung, R. L. (1998). American expatriates abroad: From neophytes to cosmopolitans. Journal of world business, 33(2), 125-144.

Van Maanen, J. (1988). Tales of the Field: On Writing Ethnography. Chicago, IL: University of Chicago Press.

Welch, C., Piekkari, R., Plakoyiannaki, E., \& Paavilainen-Mäntymäki, E. (2011). Theorising from case studies: Towards a pluralist future for international business research. Journal of International Business Studies, 42(5), 740-762.

Welch, D., \& Welch, C. (2015). How global careers unfold in practice: Evidence from international project work. International Business Review, 24(6), 1072-1081.

Welter, F. (2012). All you need is trust? A critical review of the trust and entrepreneurship literature. International Small Business Journal, 30 (3), 193-212.

Wegner, D., Koetz, C., de Oliveira Wilk, E.d and Domingos Padula, A. (2012). The influence of social capital on business performance: an analysis in Brazilian small firm networks. Paper presented at the 38th EIBA, University of Sussex, 7-9th December 2012.

Wenger, E., McDermott, R. A. \& Snyder, W. (2002). Cultivating communities of practice: A guide to managing knowledge. Harvard Business Press.

Wu, Z., Salomon, R., \& Martin, X. (2017). Complex strategic choices: a new approach with an application to adaptive agglomeration strategies among foreign entrants. Global Strategy Journal, 7 (3).

Yeung, I. Y., \& Tung, R. L. (1996). Achieving business success in Confucian societies: The importance of guanxi (connections). Organizational Dynamics, 25(2), 54-65.

Yin R. K. (2009). Case study research. Design and methods (4⿳亠丷厂 ed.) SAGE Publications.

Yli-Renko, H., Autio, E., and Sapienza, H. J. (2001). Social capital, knowledge acquisition, and knowledge exploitation in young technology-based firms. Strategic management journal, 22(6-7), 587-613.

Zhao, H. \& Hsu, C. C. (2007). Social ties and foreign market entry: An empirical inquiry. Management International Review, 47(6), 815-844. 
APPENDIX 1: Interviewees

\begin{tabular}{|c|c|c|c|c|c|c|c|}
\hline $\begin{array}{l}\text { Company } \\
\text { code }\end{array}$ & $\begin{array}{c}\text { Respon } \\
\text { dent }\end{array}$ & Date of birth & Gender & $\begin{array}{c}\text { Education } \\
\text { level }\end{array}$ & $\begin{array}{l}\text { Year working for } \\
\text { the company }\end{array}$ & $\begin{array}{l}\text { Years working for } \\
\text { the subsidiary }\end{array}$ & $\begin{array}{r}\text { Coope } \\
\text { men }\end{array}$ \\
\hline A1 & A1R1 & 1976-1981 & Male & MSc, MBA & 5 years or less & 3 years or less & $\mathrm{N}$ \\
\hline A2 & A2R1 & $1976-1981$ & Male & Bachelors & from 6 to 10 years & 3 years or less & $Y$ \\
\hline $\mathrm{A} 3$ & A3R1 & 1964-1969 & Male & MSc, MBA & from $11-15$ years & 3 years or less & $\mathrm{Y}$ \\
\hline A4 & A4R1 & $1982-1987$ & Female & Bachelors & 5 years or less & 3 years or less & $\mathrm{N}$ \\
\hline A5 & A5R1 & 1976-1981 & Male & MSc, MBA & 5 years or less & 3 years or less & $\mathrm{N}$ \\
\hline A6 & A6R1 & $1970-1975$ & Male & Bachelors & 5 years or less & 3 years or less & $\mathrm{N}$ \\
\hline A7 & A7R1 & $1976-1981$ & Male & MSc, MBA & 5 years or less & 3 years or less & $\mathrm{N}$ \\
\hline A8 & A8R1 & $1982-1987$ & Male & MSc, MBA & from 6 to 10 years & from 4 to 6 years & Y \\
\hline A9 & A9R1 & 1976-1981 & Male & MSc, MBA & 5 years or less & 3 years or less & $Y$ \\
\hline A 10 & A10R1 & $1982-1987$ & Male & MSc, MBA & from 6 to 10 years & 3 years or less & $\mathrm{Y}$ \\
\hline A11 & A11R1 & 1976-1981 & Male & MSc, MBA & from 6 to 10 years & from 4 to 6 years & $\mathrm{Y}$ \\
\hline A12 & $\mathrm{A} 12 \mathrm{R} 1$ & 1964-1969 & Male & MSc, MBA & from 6 to 10 years & 3 years or less & $\mathrm{N}$ \\
\hline A13 & A13R1 & $1952-1957$ & Male & Bachelors & from $11-15$ years & 3 years or less & \\
\hline
\end{tabular}

Source: own elaboration, 2013 
APPENDIX 2: Information about the subsidiaries in Kunshan, Jiangsu, China

\begin{tabular}{|c|c|c|c|c|c|c|c|}
\hline $\begin{array}{l}\text { Company } \\
\text { code }\end{array}$ & $\begin{array}{c}\text { Firm } \\
\text { category }\end{array}$ & $\begin{array}{c}\text { Emplo- } \\
\text { yees } \\
(2013)\end{array}$ & $\begin{array}{c}\text { Establish-ment } \\
\text { date }\end{array}$ & $\begin{array}{c}\text { Establish } \\
\text {-ment } \\
\text { reasons }\end{array}$ & Type facilities & Activity Area & Other es \\
\hline A1 & Small & 17 & $2005-2007$ & Market Seeking & Rented office & engineering and services & \\
\hline A2 & Small & 5 & $2011-2013$ & Market Seeking & Rented office & engineering and services & Engin \\
\hline A3 & Small & 130 & $2005-2007$ & Market Seeking & $\begin{array}{c}\text { Factory } 100 \% \\
\text { ownership }\end{array}$ & tooling and systems & $\begin{array}{r}\text { Purcha } \\
\text { prod }\end{array}$ \\
\hline A4 & Small & 45 & $2005-2007$ & Efficiency seeking & $\begin{array}{c}\text { Factory } 100 \% \\
\text { ownership }\end{array}$ & components & \\
\hline A5 & N/A & 5 & $2008-2010$ & Efficiency seeking & Rented office & vertical transport & \\
\hline A6 & Small & 16 & $2008-2010$ & $\begin{array}{l}\text { Market Seeking } \\
\text { Efficiency seeking }\end{array}$ & Rented factory & machine tools & Sales/co \\
\hline A7 & $\begin{array}{l}\text { Medium } \\
\text { size }\end{array}$ & 86 & $2005-2007$ & $\begin{array}{l}\text { Market Seeking } \\
\text { Efficiency seeking }\end{array}$ & $\begin{array}{c}\text { Factory } 100 \% \\
\text { ownership }\end{array}$ & construction & Sales/co \\
\hline A8 & $\begin{array}{l}\text { Medium } \\
\text { size }\end{array}$ & 53 & $2005-2007$ & Market Seeking & $\begin{array}{c}\text { Factory } 100 \% \\
\text { ownership }\end{array}$ & equipment & Product de \\
\hline A9 & Big & 163 & $2008-2010$ & Efficiency seeking & $\begin{array}{c}\text { Factory } 100 \% \\
\text { ownership }\end{array}$ & Industrial automation & $\begin{array}{l}\text { Sales/co } \\
\text { and Repr }\end{array}$ \\
\hline A 10 & Small & 70 & 2011-2013 & Market Seeking & $\begin{array}{c}\text { Factory } 100 \% \\
\text { ownership }\end{array}$ & automotive & \\
\hline A12 & Small & 70 & 2011-2013 & Market Seeking & $\begin{array}{c}\text { Factory } 100 \% \\
\text { ownership }\end{array}$ & equipment & 3 Proc \\
\hline A13 & Big & 55 & $2011-2013$ & Market Seeking & $\begin{array}{c}\text { Factory } 100 \% \\
\text { ownership }\end{array}$ & automotive & \\
\hline
\end{tabular}

Source: Orbis, 2016 and own data, 2013 


\section{APPENDIX 3: Data structure}

First other codes

\begin{tabular}{|ll|}
\hline $\begin{array}{l}\text { Strength of ties } \\
\text { (contact frequency, intimacy) } \\
\text { Collective action and cooperation }\end{array}$ & $\begin{array}{l}\text { Links direction } \\
\text { Social interaction }\end{array}$ \\
\hline \hline $\begin{array}{ll}\text { Diversity and heterogeneity } \\
\text { Density }\end{array}$ & Formality \\
$\begin{array}{ll}\text { Spatial proximity } \\
\text { Hierarchy and centrality }\end{array}$ & $\begin{array}{l}\text { Common services } \\
\text { Leadership }\end{array}$ \\
\hline
\end{tabular}

Strength of ties

(contact frequency, intimacy)

Collective action and cooperation

Diversity and heterogeneity

Density

Hierarchy and centrality

\begin{tabular}{|ll|}
\hline Membership & Mobility of workers \\
Stability of members & \\
\hline
\end{tabular}

\begin{tabular}{|ll|}
\hline $\begin{array}{l}\text { Problem resolution } \\
\text { Social solidarity }\end{array}$ & Mutual help \\
\hline
\end{tabular}

\begin{tabular}{|lrl|}
\hline $\begin{array}{l}\text { Shared goals } \\
\text { Principles and values }\end{array}$ & $\begin{array}{l}\text { Shared vision } \\
\text { Shared culture }\end{array}$ \\
\hline \hline $\begin{array}{l}\text { Existence } \\
\text { Benefits }\end{array}$ & Formation & Community connectedness \\
& Challenges & Perceptions \\
\hline
\end{tabular}

\begin{tabular}{|ll|}
\hline $\begin{array}{l}\text { Trusting climate } \\
\text { Confidence on institutions }\end{array}$ & $\begin{array}{l}\text { Confidence on others } \\
\text { Confidence on authorities }\end{array}$ \\
\hline $\begin{array}{l}\text { Value of the relationships } \\
\text { Reciprocity }\end{array}$ & Opportunistic behavior \\
\hline $\begin{array}{l}\text { Relationship with Government } \\
\text { Corruption }\end{array}$ & Lobby force \\
\hline
\end{tabular}

\section{Theoretical}
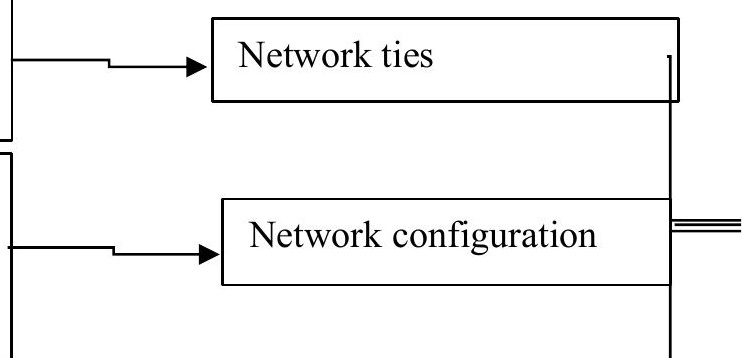

Network stability

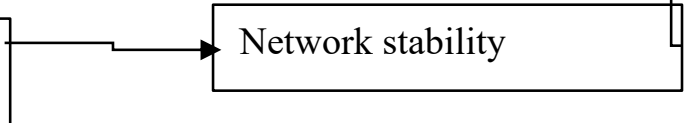

Social cohesion

Congruence level

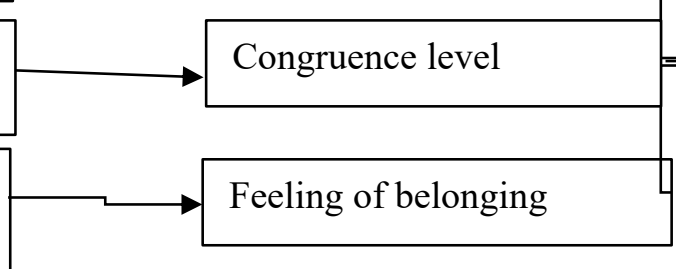

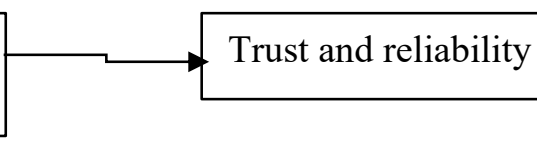

Commitment

Guanxi 


\section{APPENDIX 4: Case study protocol}

\section{FIRST EMAIL CONTACT}

- Date: 06/02/2013

- Presentation of the researcher

- Background of the research project

- Objective of the research

- Invitation to participate on the research

- Dates of possible interviews in China

- Contact details

\section{SEMI-STRUCTURED INTERVIEWS}

During March-May 2013 the fieldworker went to China to conduct the semi-structure interviews. Each of the interviews had an average extend of 90 minutes. Here we include some of the key questions of the interviews.

\section{SECTIONS OF THE INTERVIEW GUIDE}

\subsection{STRUCTURAL DIMENSION OF SOCIAL CAPITAL}

\section{- Network ties}

- How often do you interact with people from other subsidiaries in the park? With whom? For what? (to receive advice, information, experiences, any other input relevant for your firm)?

- Which are the characteristics of the firms with whom you have more formal and informal communication? (time in that market, productive activity, localization, size, position in the network)

- Does your firm collaborate on these areas? With whom? At which level?

\begin{tabular}{|c|c|c|}
\hline - $\quad$ Financial issues & $\begin{array}{l}\text { - Jointly sell products } \\
\text { or services }\end{array}$ & - Organize social events \\
\hline - Joint purchasing & - Logistics & $\begin{array}{l}\text { - Organize business } \\
\text { events }\end{array}$ \\
\hline - $\quad R \& D$ & $\begin{array}{ll}\text { - } & \begin{array}{l}\text { Transport of } \\
\text { employees }\end{array}\end{array}$ & $\begin{array}{l}\text { - Activities in the local } \\
\text { community }\end{array}$ \\
\hline $\begin{array}{l}\text { - } \begin{array}{l}\text { Recruitment and } \\
\text { selection }\end{array}\end{array}$ & - $\quad$ Training programmes & - $\quad$ Production \\
\hline $\begin{array}{l}\text { - } \quad \text { Get information } \\
\text { about business issues }\end{array}$ & $\begin{array}{ll}\text { - } & \text { Get information } \\
& \text { about personal issues }\end{array}$ & - $\quad$ Other \\
\hline
\end{tabular}

- Network configuration

- How heterogeneous are the people in the park? Which differentiating features do the people in the park have?

- How do you think the diversity (of businesses and people) is beneficial to acquire new information and access new opportunities?

- What role does the geographic proximity of firms play in their integration, communication and knowledge exchange? 
- How does the "park governance" work? (Committees, control and decision process, coordination, organization, etc.)

- Network stability

- Where do you put the boundaries of the network?

- How closed /open is the network?

- How does one become a member? That procedure is it followed?

\subsection{COGNITIVE DIMENSION OF SOCIAL CAPITAL}

- Social cohesion

- What are the triggers for everyday conflicts and misunderstandings among members of the park and how do you solve them?

- Do the park members help each other out? Do they do it often?

- Is there an acknowledgement of social obligations/ external engagement and willingness to fulfil them? Is it within the tasks and priorities of the firms?

- Congruence level

- Do park members have common goals (implicit or explicit)? What are they? Who and how are they defined?

- Do you feel identified and part of a global vision as a park? Does it give you any orientation and guidance for your work?

- What are the principles that define the management practices of the park? Do they differ a lot among subsidiaries?

- Feeling of belonging

- How important is to be located near other firms from the same country-of-origin to have a "sense of belonging" and a feeling of attachment to the place and/or people?

- Were/ are there any leaders developing a common sense of "we-ness" among the subsidiaries in the park? Could you explain what the leaders did/do to contribute to that formation?

- How is this common sense of "we-ness" perceived by the local Chinese staff members? Are there any cultural differences in the perception of the "we-ness" between the subsidiary foreign workers and local staff?

\subsection{RELATIONAL DIMENSION OF SOCIAL CAPITAL}

- Trust and reliability

- Is there in general a trusting climate in the park that makes you deal with people easily?

- Commitment

- Are you ready to invest time and money in developing the relationships between the firm members and people in the park?

- Are they given any prize or incentive those firms that take actions or assume behaviors that benefit the group?

- Is there any sanction or punishment (could be socially excluded) for the firms that take actions or assume behaviors that are detrimental/ harmful for the group?

- Guanxi

- Does your subsidiary develop and use guanxi 1) for business ties and 2) for government ties? What is the role of other members of the park developing your guanxi capabilities? 
- Is guanxi network important within the industrial park? What functional- economic value does it have? (business deals, etc.)What other values does it have? (Increase in cultural competence, etc.)

- Is your subsidiary able to extend its connections and external networks as a result of the interaction with members in the park?

- In general, do you think that as a group of Spanish/Basque firms in China you have develop the capacity to 1) identify value-creation opportunities and complementarities among members and 2) integrate network and internal resources to create synergies? 